Indigenizing the Academy: One Story

\author{
Dr. Shauneen Pete \\ Executive Lead: Indigenization, University of Regina
}

aboriginal policy studies Vol. 4, no. 1, 2015, pp. 65-72

This article can be found at:

http://ejournals.library.ualberta.ca/index.php/aps/article/view/23355

ISSN: 1923-3299

Article DOI: http://dx.doi.org/10.5663/aps.v4i1.23355

aboriginal policy studies is an online, peer-reviewed and multidisciplinary journal that publishes original, scholarly, and policy-relevant research on issues relevant to Métis, non-status Indians and urban Aboriginal people in Canada. For more information, please contact us at apsjournal@ualberta.ca or visit our website at www.ualberta.ca/nativestudies/aps/. 


\title{
Indigenizing the Academy: One Story
}

\author{
Dr. Shauneen Pete \\ Executive Lead: Indigenization, University of Regina
}

This commentary offers one story of indigenizing the academy. For me, indigenizing means re-centering Indigenous epistemes, ontologies and methodologies. I agree with Kuokkanen (2007), who says, "Indigenous epistemes have been in the academy for as long as Indigenous people have been attending universities" (p. 108). The problem is that epistemic ignorance prevails in the academy, and our ways of knowing have been marginalized, dismissed and made invisible. This story offers one example of organizational change supportive of achieving greater levels of indigenization in Canadian universities. The use of story here is intended to reposition Indigenous voices in the academy as creative, powerful, emancipatory and transformative.

\section{Recognizing Epistemic Ignorance}

As a graduate student in Educational Administration, I recognized what Kuokkanen now calls epistemic ignorance. Few of the required readings reflected anything but a dominant white, male worldview. As I brought forth readings from multiracial, feminist and Indigenous voices, my professors were generally polite but mostly uninterested in what these voices had to say. As I completed my master's courses, I began to understand that the academy was framed by a very narrow worldview; a worldview that had structurally excluded and marginalized voices other than dominant ones. I recognized that other female and/or Indigenous graduate students were clamoring for a richer understanding of scholarly work in our area of study; an understanding that included feminist, Indigenous, and other oppositional theories. During these initial explorations into other-than-dominant theories, I began to question whether my department was in fact a place where institutional transformation was even possible.

As a result of that questioning, I opted to undertake doctoral studies at the Centre for the Study of Higher Education (Administration); and because of the interdisciplinary frame of the program, I also took courses in Women and Gender Studies and American Indian Studies. I gained an understanding of the evolution of marginalized programs, and I came to recognize the transformative impact that these departments had on undergraduate student supports, resource allocation, course design and other elements of the academy. Early in the doctoral studies process I committed to the belief that the academy could, in fact, be a site for transformative change. As I planned for my doctoral research, I focussed my attention on the question, "How do Indigenous women decolonize their faculty work?" I learned that these scholars indigenize and decolonize their teaching, service and research. I also learned that much of their work was framed around resisting and confronting the epistemic ignorance of our profession. For some of the women in my sample, the work of 
confronting epistemic ignorance was viewed as a distraction from the work that drew them to the academy in the first place: informing Indigenous self-determination and sovereignty. Yet these Indigenous women scholars all recognized that there remained a grave need to ensure that universities changed.

I believed then, as I do now, that Indigenous scholars play a powerful role in (re) shaping the universities in which we work. I participate in university reform by choosing indigenizing approaches to teaching and research and actively working towards decolonizing the structures of the academy. Over the years I have been a faculty member and administrator, often leading indigenization efforts. In my first workplace, I was offered a six-month secondment to the President's office to complete the design for a conceptual framework on Aboriginal programs (2001). That framework has guided much of the work of Indigenization at that university for the past decade. I've been at the University of Regina since 2002, when I accepted a tenure-track position in the Faculty of Education. More recently, I was seconded to serve as the Executive Lead: Indigenization (2013 to present).

The following commentary explores the ways in which indigenization efforts have been undertaken at my university, the University of Regina. I believe the $\mathrm{U}$ of $\mathrm{R}$ is ideally situated to support the Indigenization efforts that are documented below.

\section{The U of R's Distinctive Federated Relationships}

The U of R has a federated relationship with three colleges: Luther College (since 1968), Campion College (since 1964), and the Saskatchewan Indian Federated College (SIFC), now known as First Nations University of Canada (FNUniv). SIFC/FNUniv has been in a federated relationship with the $\mathrm{U}$ of $\mathrm{R}$ since 1976.

I understand that over the years many individuals at the $\mathrm{U}$ of $\mathrm{R}$ took a very hands-off approach to the practice of including Indigenous worldviews, scholarship and pedagogical practices in their teaching and research work. I understand that some individuals opted out of academic inclusion because of fear of reprisal for what they thought might be construed as cultural appropriation. Some faculty maintained dominant worldviews in their areas of specialization, citing that the "canon" had to be maintained. In any case, leaving the work of indigenizing the curriculum to FNUniv meant that most $U$ of $R$ learners, including a growing number of First Nations and Métis learners, were structurally denied the opportunity to learn from other-than-dominant worldviews.

As one of a small number of Indigenous faculty (not including those at FNUniv), I often felt the burden of responsibility to provide information on all things "Indigenous"; otherwise, I feared those ways of knowing would not be provided to our students at all. To help my faculty colleagues build their own understandings, my initial tenure-stream contract was written to reflect my contributions as a faculty consultant (one who would advise, mentor and model the inclusion of Indigenous scholarship and pedagogical practices within the faculty).

At the end of my second year in a tenure-track position, I requested a leave of absence to work at FNUniv as their Vice-President (Academic). Later, I served as the Interim 
President. In both of these administrative roles, I had the great fortune to work alongside the newly appointed U of R President, Dr. Vianne Timmons.

\section{An Emerging and Expanding Vision for Indigenization}

Vianne Timmons was appointed President and Vice-Chancellor of the U of R in 2008. President Timmons has shown strong leadership in setting the course for the strategic direction of the university. She ensured that the last strategic plan, mamawohkamatowin (Cree, "working together towards common goals") was fully implemented. Indigenization was identified as a strategic goal; this was reflected in one aspect of the $U$ of $R$ mission to "respond to the needs of Saskatchewan peoples, particularly First Nations and Métis peoples" (U of R, 2009, 3). Additionally, a strategic objective was to "build long-term relationships with First Nations and Métis Communities" (U of R, 2009, 5). President Timmons has played an instrumental role in the Indigenization efforts at the $\mathrm{U}$ of $\mathrm{R}$. Under her leadership, we have seen the strengthening of relationships with FNUniv, the expansion of the Aboriginal Student Center (ASC) and the establishment of an Aboriginal Advisory Circle (AAC).

The AAC advises the President on strategies to support Indigenization. Its members recommended the establishment of the Executive Lead: Indigenization position. The Lead takes her direction from the priorities identified by AAC members in their strategic direction document, Strong Voice, Strong Plan (2013). We believe that Indigenization

refers to the transformation of the existing academy by including Indigenous knowledges, voices, critiques, scholars, students and materials as well as the establishment of physical and epistemic spaces that facilitate the ethical stewardship of a plurality of Indigenous knowledges and practices so thoroughly as to constitute an essential element of the university. It is not limited to Indigenous people, but encompasses all students and faculty, for the benefit of our academic integrity and our social viability. (AAC, 2012)

Our strategic planning document identified four key priorities: to develop and implement a communication strategy; continue academic Indigenization; implement a community engagement strategy; and increase the visibility and frequency of Indigenous events and activities on campus. The aim of these priorities is to build a shared understanding of Indigenization in order to bring about a shared responsibility for Indigenization.

In my role as the Lead, I delivered 32 information sessions to administrative and academic units in order to introduce our AAC vision for Indigenization. We offered a series of workshops and events, including the Indigenizing our Teaching speaker series, an Idle No More presentation, and the RED/talk event (Four Indigenous intellectuals were asked the question, "What does a post-Indian Act future in Canada look like?"). We hosted 100 Years of Loss (a residential schools installation), and offered our first ever First Nations, Metis and Inuit Research Showcase featuring 26 presentations by over 50 presenters. We invited and/ or were visited by Indigenous scholars like Dr. Joe Graham (New Mexico State University), 
Dr. Roe Bubar (Colorado State University), and Dr. Shawn Wilson (University of Sydney). We feel that our first year was hugely successful.

More recently, I served as one of the team members on the university strategic planning facilitation team. I am pleased to say that Indigenization efforts will only become more intense in the years ahead as expressed in Peyak Aski Kikawinaw, the new $\mathrm{U}$ of $\mathrm{R}$ strategic plan. Two overarching themes of the new strategic plan are: sustainability and Indigenization. These two themes filter through our responsibilities for teaching, research and service to our communities. A number of objectives and outcomes have been identified that will guide the work of faculty, staff and administration over the next five years. We believe the new strategic direction for the university will result in greater coordination of Indigenization efforts across the campus with an aim of embedding Indigenization in every academic and administrative unit. Our intention is to lay a strong foundation for greater levels of institutional change.

\section{Laying a Strong Foundation for Indigenization}

The University of Regina is situated in Treaty 4 Territory. This geographic location is home to twenty-seven First Nations communities (all Cree, Saulteaux, or Sioux) and four historically Métis communities (Lebret, Fort Qu'Appelle, Lestock, and Willow Bunch), as well as an ever-increasing urban population of Indigenous peoples (Statistics Canada, 2010). Treaty 4 was signed in Fort Qu'Appelle, and Regina is also the location of the trial and execution of the Métis leader Louis Riel. Our location is fraught with the historical legacies that colonization has provided. We believe we have a responsibility to teach about the legacy of this place that we currently live in.

The members of the AAC also come from diverse backgrounds: we are Métis and First Nations peoples; we are Cree, Ojibway, Salteaux, and Sioux, and several of us are a mixture of these identities. The AAC is also comprised of volunteers from both staff and faculty ranks. Faculty from FNUniv and the Saskatchewan Urban Native Teacher Education Program (SUNTEP) have been invited to serve as members.

Because of our diversities, as we developed the path toward Indigenization we have wrestled with the idea of "pimatisiwin" - "doing things in a good way." In our collegial work, we have opted to respect our diversity in the following important ways: first, we encouraged each other to individualize our relationships with Elders and traditional knowledge keepers as one way to broaden the scope of our vision for Indigenization, as opposed to becoming locked into the teachings of a particular Elder to the exclusion of other voices; second, we decided that if it is our way, then individuals would smudge prior to coming to our meetings, as opposed to requiring the whole group to smudge at the beginning of the meeting. We felt that the requirement to smudge publically could exclude some individuals, and our intention was to work in an inclusive manner. These negotiations were undertaken in the spirit of respect for our diversity as a group and with respect for pimatisiwin in the process of our collective work. 
As we began to formalize our indigenization efforts, it was also important for us to explore the role that ceremony could play in our work. For example, we discussed whether to hold a sweat; we quickly realized that cultural protocols differed for several of our members, whereby, in their home communities men and women did not attend a sweat together. Alternatively, we agreed to encourage one member who took tobacco and cloth to a sweat on our behalf, even when participation in sweat was not everyone's way. It was important for us to recognize the differences in ceremonial practices by which we are shaped, for we also recognized that to engage in arguments about which good way to do things would do little to expand our efforts to indigenize. Laying a strong foundation for indigenization is often a messy part of the work, yet in a spirit of enacting changes that were intended to be long-lasting, we felt it important to take the time to engage in these discussions fully.

\section{Emerging Policy Need}

As we continued to do work in a good way, institutional policy reforms emerged. For example, a new faculty member received a start-up grant from the university to begin her research agenda. She decided to honor the gift by hosting a feast and round dance. This faculty member, Dr. JoLee Sasakamoose (Blackbear) was committed to pimatisiwin. Her efforts to hold a feast and round dance resulted in a number of institutional challenges that necessitated policy reform in three areas: smudging, pipe ceremony, and cultural feasting policy.

These policy reforms required a series of discussions about the role of ceremony and the work of Elders on the one hand, and the university's occupational health and safety policies on the other. As I met with administrators and managers in Facilities Management, Student Services, Catering Services, Human Resources, and Financial Services I was encouraged by their willingness to reform policy and procedures. I was also encouraged by their desire to explore how our ways of knowing could be accommodated in the academy. I maintain that efforts to reform university policy were essential foundational steps necessary to support the AAC in actualizing greater levels of Indigenization at our university.

\section{Indigenizing our Teaching: Professional Development and Scholarship}

Before engaging widely with faculty at the university to find out how they were indigenizing their teaching, I thought I had better first have the conversation with Indigenous colleagues. I received a university research grant to undertake a study, and invited Indigenous faculty colleagues to participate. I organized two talking circles in which we explored how we were Indigenizing our own teaching. My colleagues stated that they were reclaiming traditional knowledges through their relationships with Elders, and practicing more traditional knowledge transfer activities such as "kitchen table talk" (a form of informal storytelling), documenting traditional crafts, and practicing Indigenous languages. They also re-centered the voices of Indigenous scholars in their course outlines, invited guest speakers to address their students, and offered their learners hands-on experiential learning opportunities. This 
project became a starting point for the development of the Indigenizing our Teaching series that I organized. I invited some of my Indigenous colleagues to share their approaches to planning for learning, and invited mainstream colleagues to speak to their experiences as well. This six-part series was well-attended by faculty from across campus.

Aligned with these professional development opportunities, indigenizing our teaching also became a topic for other scholarly activities. A colleague and I began a self-study into our Indigenizing practices in our courses. I co-authored an article with two colleagues from First Nations University of Canada (FNUniv) on our approaches to indigenizing our teaching in education and business (Pete, Schneider \& O’Reilly, 2013). More recently, Dr. Sasakamoose and I have submitted two papers for peer review that centre on the challenges of policy reform that we encountered when she hosted the feast and round dance.

Indigenization as both institutional action and area of scholarship is a priority for me. Canadian universities are actively moving ahead on Indigenization, yet there remains a paucity of research on this topic; I feel that we must make it a priority to document along the way. In this way, we can offer other universities one approach to moving forward.

\section{The Path Toward Greater Levels of Indigenization}

As stated earlier, the new university strategic plan names Indigenization as an overarching priority. With this priority in mind, AAC members undertook their own strategic planning event, which imagined increasingly transformative changes that could only be initialized and sustained through the development of an Office of Indigenization.

For the last year-and-a-half, the Executive Lead has worked in her faculty office with no administrative support, although with some financial supports to offer services across the university. In order to enhance our ability to inform the strategic directions of the university effectively, we require an office dedicated to leadership that will support the goals identified in the new university strategic plan. The members of the AAC imagine an actual physical office space that would accommodate the Executive Lead and an administrative assistant. To go farther, we determined that we will need three additional positions:

1. A community engagement officer responsible for the growth of our Aboriginal alumni association and responsible for community outreach, promotion and research partnership development.

2. A communications officer whose responsibilities would include development of the website; of promotional materials to communicate information on Indigenous researchers and disseminate Indigenous scholarship; and of a communications strategy aimed at First Nations and Métis peoples, communities and organizations.

3. A research officer responsible for consultation and contracted research with Indigenous peoples, communities and organizations; promotion of Indigenous and community-based research methods; and building our capacity for successfully securing Tri-Council funding.

4. While we recognize that our ambitious vision for Indigenization could be viewed as being at odds with the dominant neoliberal trend toward university reorganization and downsizing, we feel that without an earnest resource allocation into this change effort, Indigenization at our university cannot and will not be possible. 


\section{Conclusion}

At the $\mathrm{U}$ of $\mathrm{R}$, we have learned that Indigenization efforts are not generalizeable but must reflect the communities in which the efforts are undertaken. In our case, our communities are diverse, as are members of the AAC, and so too are our approaches to organizational change. We have built a strong foundation for Indigenization because it is one of the overarching priorities of the university's strategic plan. We maintain that academic indigenization is about identifying, resisting and correcting forms of epistemic ignorance, and we do so by correcting university policy, altering the norms of course design, and engaging in research differently - and now we are challenging normative views on resource and space allocations. We continue to move towards a shared responsibility for indigenization. As colleagues in the knowledge production process, we must collaborate in the deconstruction of university norms in order to transform the existing academy in lasting and powerful ways. We offer this story as one narrative about university indigenization. We hope that you find within it some inspiration for your own work. 


\section{Bibliography}

Aboriginal Advisory Circle. 2012. Strong Voice, Strong Plan. Unpublished strategic plan.

Kuokkanen, R. 2007. Reshaping the University: Responsibility, Indigenous Epistemes, and the Logic of the Gift. Vancouver: UBC Press.

Pete, S., Schneider, B., and O'Reilly, K. 2013. "Decolonizing our Practice - Indigenizing our Teaching." First Nations Perspectives: The Journal of the Manitoba first Nations Education Resource Centre Inc. 5(1): 99-115.

Statistics Canada. 2010. 2006 Aboriginal Population Profile for Regina. Catalogue number 89-638-X-no. 2010003. Accessed [August 14, 2014] from http://www.statcan.gc.ca/ pub/89-638-x/2010003/article/11079-eng.pdf.

University of Regina. 2009. Mâmawohkamâtowin: Our Work, Our People, Our Communities Unpublished strategic plan. Accessed [August 14, 2014] from http://www.uregina. ca/strategic-plan/.

University of Regina. 2015. Peyak Aski Kikawinaw: Together we are Stronger. Unpublished strategic plan. Accessed [January 10, 2015] from http://www.uregina.ca/strategicplan/. 